\title{
EVALUASI PELAKSANAAN CARA DISTRIBUSI OBAT YANG BAIK (CDOB) DI APOTEK WILAYAH KECAMATAN CIKUPA KABUPATEN TANGERANG
}

\section{EVALUATION OF GOOD DISTRIBUTION PRACTICE (GDP) IMPLEMENTATION IN PHARMACY AT CIKUPA TANGERANG}

\author{
Jaka Supriyanta ${ }^{1^{*}}$, Ghita Ananda El-Haque ${ }^{1}$, Trisna Lestari ${ }^{1}$ \\ ${ }^{1}$ Sekolah Tinggi Farmasi Muhammadiyah Tangerang \\ ${ }^{*}$ Corresponding Author Email : jokosupriyanto0710@gmail.com \\ DOI: http://dx.doi.org/10.47653/farm.v7i2.183
}

\begin{abstract}
ABSTRAK
Distribusi obat merupakan suatu proses yang penting dalam menjaga efikasi, keamanan, dan kualitas suatu obat, pedoman Cara Distribusi Obat yang Baik (CDOB) perlu diterapkan pada fasilitas Apotek agar mutu obat dapat terjamin sampai ke tangan pasien. CDOB adalah cara distribusi atau penyaluran obat dan atau bahan obat yang bertujuan memastikan mutu sepanjang jalur distribusi atau penyaluran sesuai persyaratan dan tujuan penggunaannya. Penelitian ini bertujuan untuk mengetahui kesesuaian pendistribusian obat di Apotek Wilayah Kecamatan Cikupa Kabupaten Tangerang berdasarkan Peraturan Kepala BPOM Nomor HK.03.1.34.11.12.7542 Tahun 2012. Metode penelitian bersifat deskriptif dengan memberikan kuisioner ke Apotek yang ada di Wilayah Kecamatan Cikupa Kabupaten Tangerang yang meliputi aspek profil sarana, bangunan dan peralatan, pengadaan, penerimaan dan penyimpanan, penyaluran, penanganan produk kembali dan kadaluarsa, dan pemusnahan. Berdasarkan hasil penelitian pelaksanaan CDOB kesesuaian dengan Peraturan Kepala BPOM Nomor HK.03.1.34.11.12.7542 Tahun 2012 di Apotek Wilayah Kecamatan Cikupa, pada aspek profil sarana sebesar $77,3 \%$, aspek bangunan dan peralatan sebesar $83,3 \%$, aspek pengadaan sebesar $72.2 \%$, aspek penerimaan dan penyimpanan sebesar $91,1 \%$, aspek penyaluran sebesar $44,4 \%$, aspek penanganan produk kembalian dan kadaluarsa sebesar $73,3 \%$, dan aspek pemusnahan sebesar $68,3 \%$.

Kata Kunci: Cara Distribusi Obat yang Baik, Apotek, Kecamatan Cikupa
\end{abstract}

\section{ABSTRACT}

Drug distribution is an important process in maintaining the efficacy, safety and quality of a drug, guidelines for Good Distribution Practice (GDP) should be implemented in Pharmacy facilities so that the quality of the drug can be guaranteed to the patient's hands. GDP is a method of distribution or distribution of drugs and or medicinal ingredients aimed at ensuring quality along the distribution channels according to the requirements and purposes of their use. The study aims to determine the suitability of drug distribution in the Cikupa District Pharmacy of Tangerang Regency based on the Head of BPOM Regulation Number HK.03.1.34.11.12.7542 in 2012. The research method is descriptive by giving questionnaires to the pharmacy in the Cikupa District of Tangerang Regency which covers aspects profile of facilities, buildings and equipment, procurement, receipt and storage, distribution, product handling of product returns and expire date, and destruction. According to data collected of the study implementation of the GDP in accordance with the head of BPOM Regulation Number HK.03.1.34.11.12.7542 In 2012 at the Cikupa District Pharmacy, in the aspect profile of facility at $77,3 \%$, building and equipment to $83,3 \%$, procurement aspect was $72,2 \%$, the acceptance and storage aspects amounted to $91,1 \%$, the distribution aspect was $44,4 \%$, the handling and return of expiration products were $73,3 \%$, and the destruction aspect was $68,3 \%$.

Keywords: Good Distribution Practice, Pharmacy, Cikupa District

\section{PENDAHULUAN}

Apotek adalah suatu tempat tertentu untuk melakukan pekerjaan kefarmasian dan penyerahan sediaan farmasi dan perbekalan kesehatan lainnya kepada masyarakat (PerKa BPOM, 2012). Apotek menyelenggarakan fungsinya seperti pengelolaan sediaan farmasi, 
alat kesehatan, dan bahan medis habis pakai, dan pelayanan farmasi klinik, termasuk di komunitas (Permenkes, 2017).

Obat adalah bahan atau paduan bahan, termasuk produk biologi, yang digunakan untuk memengaruhi atau menyelidiki sistem fisiologi atau keadaan patologi dalam rangka penetapan diagnosis, pencegahan, penyembuhan, pemulihan, peningkatan kesehatan dan kontrasepsi untuk manusia (PerKa BPOM, 2012).

Pada tahap pembuatan obat, pemerintah sudah membuat suatu pedoman yaitu Cara Pembuatan Obat yang Baik (CPOB) agar obat dapat memenuhi kriteria efficacy, safety dan quality. Sedangkan pada proses distribusinya pun pemerintah telah membuat suatu peraturan mengenai Cara Distribusi Obat yang Baik (CDOB), peraturan tersebut tercantum dalam Peraturan Kepala Badan Pengawas Obat Dan Makanan Republik Indonesia Hk.03.1.34.11.12.7542 Tahun 2012 tentang Pedoman Teknis Cara Distribusi Obat yang Baik (CDOB). Cara Distribusi Obat yang Baik (CDOB) adalah cara distribusi atau penyaluran obat dan atau bahan obat yang bertujuan memastikan mutu sepanjang jalur distribusi atau penyaluran sesuai persyaratan dan tujuan penggunaannya. Kegiatan yang menyangkut distribusi obat meliputi pengadaan, penyimpanan, dan penyaluran obat dari produsen hingga ketangan konsumen. Penerapan CDOB ini diharapkan dapat mempertahankan dan memastikan bahwa mutu obat yang diterima oleh pasien sama dengan mutu obat yang dikeluarkan oleh industri farmasi (Hartini, 2016).

\section{METODE PENELITIAN}

Penelitian ini merupakan penelitian deskriptif non eksperimental dengan pendekatan kualititatif di Apotek Wilayah Kecamatan Cikupa Kabupaten Tangerang. Penelitian ini menggunakan formulir kuisoner yang diisi oleh responden. Populasi dalam penelitian ini adalah semua Apotek di Wilayah Kecamatan Cikupa Kabupaten Tangerang yang berjumlah 22 Apotek berdasarkan data dari Dinas Kesehatan Kabupaten Tangerang.pengumpulan data dilakukan menggunakan formulir kuisoner yang terdiri dari aspek profil sarana, bangunan, peralatan, pengadaan, penerimaan, penyimpanan, penyaluran, penanganan produk kembalian dan kadaluarsa, dan pemusnahan. Data yang di dapat kemudian di analisis secara kualitatif untuk diterapkan di Apotek Wilayah Kecamatan Cikupa sesuai dengan kriteria temuan yang di dapat.

\section{HASIL DAN PEMBAHASAN}

Penelitian ini dilakukan di Apotek Wilayah Kecamatan Cikupa Kabupaten Tangerang dengan menggunakan metode deskriptif yang disajikan dalam bentuk tabel. Penelitian ini dilakukan dengan cara membagikan kuisioner kepada semua Apotek yang terdaftar di Dinas Kesehatan Kabupaten Tangerang pada Tahun 2018. Peneliti terlebih dahulu melakukan permohonan izin kepada Dinas Kesehatan Kabupaten Tangerang untuk mendapatkan daftar nama Apotek, setelah menerima daftar Apotek, peneliti melakukan permohonan izin ke semua Apotek Wilayah Kecamatan Cikupa Kabupaten Tangerang. Setelah permohonan izin diterima peneliti langsung melakukan penelitian.

Pelaksanaan Cara Distribusi Obat yang Baik (CDOB) di Apotek Wilayah Cikupa Kabupaten Tangerang yaitu meliputi Aspek Profil Sarana, Bangunan dan Peralatan, Pengadaan, Penerimaan dan Penyimpanan, Penyaluran, Penanganan Produk kembalian dan kadaluarsa, dan Pemusnahan. Berdasarkan aspek tersebut dapat diketahui gambaran pelaksanaan CDOB pada Apotek di Wilayah Kecamatan Cikupa Kabupaten Tangerang, untuk masing-masing aspek.

\section{Aspek Profil Sarana}

Aspek Profil Sarana di dapat dari lima belas Apotek di Wilayah Kecamatan Cikupa Kabupaten Tangerang, data dapat dilihat pada tabel 1.

Tabel 1. Aspek Profil Sarana

\begin{tabular}{|c|c|c|c|}
\hline No & Aspek Profil Sarana & Ya & Tidak \\
\hline 1. & $\begin{array}{l}\text { Apotek memiliki Apoteker } \\
\text { pendamping. }\end{array}$ & $26,7 \%$ & $73,3 \%$ \\
\hline 2. & $\begin{array}{l}\text { Apotek terdapat struktur } \\
\text { organisasi. }\end{array}$ & $73,3 \%$ & $26,7 \%$ \\
\hline 3. & $\begin{array}{l}\text { Apotek memasang papan } \\
\text { nama Apotek. }\end{array}$ & $100 \%$ & $0 \%$ \\
\hline 4. & $\begin{array}{l}\text { Apotek memasang papan } \\
\text { praktik Apoteker. }\end{array}$ & $86,7 \%$ & $13,3 \%$ \\
\hline 5. & $\begin{array}{l}\text { Apotek tersedia buku } \\
\text { referensi (buku standar } \\
\text { dan kumpulan peraturan } \\
\text { perundang-undangan } \\
\text { yang berhubungan). }\end{array}$ & $100 \%$ & $0 \%$ \\
\hline & Total & $77,3 \%$ & $22,7 \%$ \\
\hline
\end{tabular}

Berdasarkan tabel 1 dapat dilihat pada aspek profil sarana yang sesuai dengan 
Peraturan Kepala BPOM tahun 2012 tentang Cara Distribusi Obat yang Baik (CDOB) yaitu $77,3 \%$ sesuai dengan Peraturan Kepala BPOM Tahun 2012 dan 22,7\% tidak sesuai dengan Peraturan Kepala BPOM Tahun 2012 yaitu "Pelaksanaan dan pengelolaan sistem manajemen mutu yang baik serta distribusi obat dan atau bahan obat yang benar sangat bergantung pada personil yang menjalankannya. Harus ada personil yang cukup dan kompeten untuk melaksanakan semua tugas yang menjadi tanggung jawab fasilitas distribusi. Tanggung jawab masingmasing personil harus dipahami dengan jelas dan dicatat. Semua personil harus memahami prinsip CDOB dan harus menerima pelatihan dasar maupun pelatihan lanjutan yang sesuai dengan tanggung jawabnya". Berdasarkan hal tersebut dalam sebuah Apotek harus mempunyai manajerial yang bagus, dengan cara membuat struktur organisasi. Hal ini berfungsi agar tugas-tugas terorganisir dengan rapih dan personil-personil di Apotek dapat menjalankan tanggung jawabnya dengan kompeten, serta dapat menyelesaikan segala permasalahan yang ada di Apotek. Sistem manajemen yang baik akan membawa Apotek kepada kepuasan pelanggan dan kenyamanan dalam bekerja.

\section{Aspek Bangunan dan Peralatan}

Aspek Bangunan dan Peralatan di dapat dari lima belas Apotek di Wilayah Kecamatan Cikupa Kabupaten Tangerang, data dapat dilihat pada tabel 2 .

Tabel 2. Aspek Bangunan dan Peralatan

\begin{tabular}{|c|c|c|c|}
\hline No & $\begin{array}{l}\text { Aspek Bangunan dan } \\
\text { Peralatan }\end{array}$ & Ya & Tidak \\
\hline 1. & $\begin{array}{l}\text { Tersedia ruang tunggu bagi } \\
\text { pasien. }\end{array}$ & $66,7 \%$ & $33,3 \%$ \\
\hline 2. & $\begin{array}{llr}\text { Tersedia ruangan tertutup } & \text { ruang } \\
\text { untuk konseling } & \text { bagi } \\
\text { pasien. } & & \end{array}$ & $60 \%$ & $40 \%$ \\
\hline 3. & $\begin{array}{l}\text { Atap Apotek dalam } \\
\text { keadaan baik dan tidak } \\
\text { bocor. }\end{array}$ & $100 \%$ & $0 \%$ \\
\hline 4. & $\begin{array}{l}\text { Penerangan Apotek yang } \\
\text { cukup. }\end{array}$ & $100 \%$ & $0 \%$ \\
\hline 5. & $\begin{array}{lr}\text { Tersedia } & \text { timbangan } \\
\text { miligram dan } & \text { anak } \\
\text { timbangan. } & \end{array}$ & $100 \%$ & $0 \%$ \\
\hline 6. & Tersedia wastafel. & $100 \%$ & $0 \%$ \\
\hline 7. & $\begin{array}{l}\text { Tersedia pallet atau papan } \\
\text { alas untuk menyimpan } \\
\text { barang. }\end{array}$ & $66,7 \%$ & $33 \%$ \\
\hline 8. & Tersedia alat pendingin & $100 \%$ & $0 \%$ \\
\hline
\end{tabular}

ruangan atau $\mathrm{AC}$.

9. Tersedia rak atau lemari $100 \% \quad 0 \%$ penyimpanan obat.

10. Tersedia lemari pendingin $93,3 \% \quad 6,7 \%$ untuk menyimpan jenis obat-obat tertentu yang memerlukan suhu dingin.

11. Tersedia lemari khusus 93,3\% 6,7\% untuk penyimpanan narkotika dan psikotropika.

12. Tersedia lemari khusus $53,3 \% \quad 46,7 \%$ untuk obat rusak dan kadaluarsa.

13. Adanya pengaturan suhu $100 \% \quad 0 \%$ ruangan.

14. Adanya pengaturan suhu $93,3 \% \quad 6,7 \%$ lemari pendingin.

15. Adanya pengaturan $46,7 \% \quad 53,3 \%$ kelembaban.

16. Tersedia catatan $80 \% \quad 20 \%$ monitoring suhu.

17. Tersedia catatan $\quad 46,7 \% \quad 53,3 \%$ monitoring kebersihan.

18. Tersedia alat Pemadam 100\% $0 \%$ Api Ringan (APAR). Total $83.3 \% \quad 16.7 \%$

Berdasarkan tabel 2 dapat dilihat Apotek yang sesuai dengan Peraturan Kepala BPOM Tahun 2012 sebanyak 83,3\% dan 16,7\% tidak sesuai dengan Peraturan Kepala BPOM Tahun 2012 yaitu "Fasilitas distribusi harus memiliki bangunan dan peralatan untuk menjamin perlindungan dan distribusi obat dan atau bahan obat. Bangunan harus dirancang dan disesuaikan untuk memastikan bahwa kondisi penyimpanan yang baik dapat dipertahankan, mempunyai keamanan yang memadai dan kapasitas yang cukup untuk memungkinkan penyimpanan dan penanganan obat yang baik, dan area penyimpanan dilengkapi dengan pencahayaan yang memadai untuk memungkinkan semua kegiatan dilaksanakan secara akurat dan aman".

\section{Aspek Pengadaan}

Aspek Pengadaan didapat dari lima belas Apotek di Wilayah Kecamatan Cikupa Kabupaten Tangerang, data dapat dilihat pada tabel 3.
Tabel 3. Aspek Pengadaan

No Aspek Pengadaan Ya




\begin{tabular}{|c|c|c|c|}
\hline 1. & $\begin{array}{l}\text { Pengadaan obat dilakukan } \\
\text { secara kontinue, untuk } \\
\text { mencegah kekosongan } \\
\text { salah satu jenis obat. }\end{array}$ & $100 \%$ & $0 \%$ \\
\hline 2. & $\begin{array}{l}\text { Apotek memesan atau } \\
\text { membeli obat dari PBF. }\end{array}$ & $93,3 \%$ & $6,7 \%$ \\
\hline 3. & $\begin{array}{l}\text { Apotek memperoleh obat } \\
\text { dari pemasok yang memiliki } \\
\text { izin. }\end{array}$ & $100 \%$ & $0 \%$ \\
\hline 4. & $\begin{array}{l}\text { Setiap obat yang dipesan } \\
\text { atau dibeli, selalu disertai } \\
\text { faktur pembelian. }\end{array}$ & $100 \%$ & $0 \%$ \\
\hline 5. & $\begin{array}{l}\text { Apotek menyediakan obat } \\
\text { golongan Narkotika. }\end{array}$ & $13,3 \%$ & $86,7 \%$ \\
\hline 6. & $\begin{array}{l}\text { Apotek menyediakan obat } \\
\text { golongan psikotropika. }\end{array}$ & $26,7 \%$ & $73,3 \%$ \\
\hline \multicolumn{2}{|r|}{ Total } & $72,2 \%$ & $27,8 \%$ \\
\hline
\end{tabular}

Berdasarkan tabel 3 dapat dilihat yang sesuai dengan Peraturan Kepala BPOM Tahun 2012 pada aspek pengadaan yang sesuai dengan Peraturan Kepala BPOM Tahun 2012 yaitu $72,2 \%$, dan $27,8 \%$ tidak sesuai dengan Peraturan Kepala BPOM Tahun 2012. Berdasarkan penelitian dari Isna Sugih Hartini dan Marchaban aspek pengadaan yaitu "Aspek ini berisi mengenai bagaimana barang atau obat yang disediakan itu dipesan, mulai dari sumber pengadaan sampai kelengkapan surat-surat saat proses pemesanan barang yang dalam hal ini berupa obat dan atau bahan obat". Hal ini sesuai dengan Permenkes Nomor 73 Tahun 2016 yaitu "Untuk menjamin kualitas Pelayanan Kefarmasian maka pengadaan Sediaan Farmasi harus melalui jalur resmi sesuai ketentuan peraturan perundang-undangan". Apotek di wajibkan membeli stok obat melalui jalur resmi, hal ini di karenakan agar keaslian dan mutu obat terjamin, sedangkan jika obat di peroleh dari jalur yang tidak resmi memungkinkan masuknya obat palsu dan mutu obat tidak terjamin. Pembelian pun harus disertai faktur agar aman dalam transaksi dan sah dalam proses pembelian sehingga terhindar dari audit.

\section{Aspek Penerimaan dan Penyimpanan}

Aspek penerimaan dan penyimpanan di dapat dari lima belas Apotek di Wilayah Kecamatan Cikupa Kabupaten Tangerang, data dapat dilihat pada tabel 4 .

Tabel 4. Aspek Penerimaan dan Penyimpanan No Aspek Penerimaan dan $\quad$ Ya Tidak

\begin{tabular}{|c|c|c|c|}
\hline \multicolumn{3}{|c|}{ Penyimpanan } & \multirow[b]{2}{*}{$6,7 \%$} \\
\hline 1. & $\begin{array}{l}\text { Nomor bets dan tanggal } \\
\text { kadaluarsa obat dan atau } \\
\text { bahan obat dicatat pada } \\
\text { saat penerimaan. }\end{array}$ & $93,3 \%$ & \\
\hline 2. & $\begin{array}{l}\text { Nama pemasok dicatat } \\
\text { pada saat penerimaan. }\end{array}$ & $86,7 \%$ & $\begin{array}{l}13,3 \\
\%\end{array}$ \\
\hline 3. & $\begin{array}{l}\text { Alamat pemasok dicatat } \\
\text { pada saat penerimaan. }\end{array}$ & $86,7 \%$ & $\begin{array}{l}13,3 \\
\%\end{array}$ \\
\hline 4. & $\begin{array}{l}\text { Penyimpanan obat LASA } \\
\text { (look alike sound alike) } \\
\text { tidak ditempatkan } \\
\text { berdekatan dan diberi } \\
\text { penandaan khusus obat. }\end{array}$ & $73,3 \%$ & $\begin{array}{l}26,7 \\
\%\end{array}$ \\
\hline 5. & $\begin{array}{l}\text { Penyimpanan obat sesuai } \\
\text { metode FIFO. }\end{array}$ & $100 \%$ & $0 \%$ \\
\hline 6. & $\begin{array}{l}\text { Penyimpanan obat sesuai } \\
\text { metode FEFO. }\end{array}$ & $100 \%$ & $0 \%$ \\
\hline 7. & $\begin{array}{l}\text { Penyimpanan obat } \\
\text { berdasarkan jenis obat. }\end{array}$ & $100 \%$ & $0 \%$ \\
\hline 8. & $\begin{array}{lr}\text { Penyimpanan } & \text { obat } \\
\text { berdasarkan } & \text { bentuk } \\
\text { sediaan. } & \end{array}$ & $100 \%$ & $0 \%$ \\
\hline 9. & $\begin{array}{lr}\text { Penyimpanan } & \text { obat } \\
\text { berdasarkan } & \text { alfabert } \\
\text { (abjad). } & \end{array}$ & $73,3 \%$ & $\begin{array}{l}26,7 \\
\%\end{array}$ \\
\hline 10. & $\begin{array}{l}\text { Obat yang rusak } \\
\text { diletakan terpisah dengan } \\
\text { obat yang masih baik. }\end{array}$ & $100 \%$ & $0 \%$ \\
\hline 11. & $\begin{array}{l}\text { Obat yang kadaluarsa } \\
\text { diletakan terpisah dengan } \\
\text { obat yang masih baik. }\end{array}$ & $100 \%$ & $0 \%$ \\
\hline 12. & $\begin{array}{l}\text { Diberikan } \\
\text { nelabelan } \\
\text { nama obat pada rak } \\
\text { penyimpanan }\end{array}$ & $73,3 \%$ & $\begin{array}{l}26,7 \\
\%\end{array}$ \\
\hline 13. & $\begin{array}{l}\text { Penggunaan instruksi } \\
\text { penyimpanan obat } \\
\text { mengikuti petunjuk yang } \\
\text { tertera pada label obat. }\end{array}$ & $86,7 \%$ & $\begin{array}{l}13,3 \\
\%\end{array}$ \\
\hline \multirow[t]{4}{*}{14.} & $\begin{array}{l}\text { Kategori penyimpanan } \\
\text { obat berdasarkan : }\end{array}$ & & \\
\hline & $\begin{array}{l}\text { Suhu dingin (vaksin, } \\
\text { suppositoria, insulin, } \\
\text { serum dll). }\end{array}$ & $93,3 \%$ & $6,7 \%$ \\
\hline & $\begin{array}{l}\text { Suhu Ruang (Tablet, } \\
\text { kapsul,salep,syrup). }\end{array}$ & $100 \%$ & $0 \%$ \\
\hline & $\begin{array}{l}\text { Total } \\
\end{array}$ & $91,1 \%$ & $8,9 \%$ \\
\hline
\end{tabular}

Berdasarkan tabel 4 terdapat $91,1 \%$ Apotek yang sesuai dengan Peraturan Kepala BPOM Tahun 2012 dan 8,9\% tidak sesuai dengan Peraturan Kepala BPOM Tahun 2012 yaitu "Proses penerimaan bertujuan untuk memastikan bahwa kiriman obat dan atau bahan obat yang diterima benar, berasal dari pemasok yang disetujui, tidak rusak atau tidak mengalami perubahan selama transportasi dan Penyimpanan dan penanganan obat dan atau bahan obat harus mematuhi peraturan perundang-undangan". Berdasarkan hal 
tersebut maka penyimpanan harus sesuai karena untuk menghindari kesalahan, kestabilan obat-obatan dan kontaminasi atau tercampurnya obat-obat yang bentuk maupun jenis yang berbeda.

\section{Aspek Penyaluran}

Aspek penyaluran didapat dari lima belas Apotek di Wilayah Kecamatan Cikupa Kabupaten Tangerang, data dapat dilihat pada tabel 5.

Tabel 5. Aspek Penyaluran

\begin{tabular}{|c|c|c|c|}
\hline No & Aspek Penyaluran & Ya & Tidak \\
\hline 1. & $\begin{array}{l}\text { Apotek melayani obat } \\
\text { keras (diluar OWA) } \\
\text { dengan resep dokter. }\end{array}$ & $93,3 \%$ & $6,7 \%$ \\
\hline 2. & $\begin{array}{l}\text { Apotek melayani sediaan } \\
\text { narkotika dengan resep } \\
\text { dokter. }\end{array}$ & $13,3 \%$ & $86,7 \%$ \\
\hline 3. & $\begin{array}{l}\text { Apotek melayani sediaan } \\
\text { psikotropika dengan } \\
\text { resep dokter. }\end{array}$ & $26,7 \%$ & $73,3 \%$ \\
\hline & Total & $44,4 \%$ & $55,6 \%$ \\
\hline
\end{tabular}

Berdasarkan tabel 5 terdapat $44,4 \%$ Apotek yang sesuai dengan Peraturan Kepala BPOM Tahun 2012 dan 55,6\% tidak sesuai. Berdasarkan penelitian dari Isna Sugih Hartini dan Marchaban yaitu "Aspek ini berkaitan dengan proses penyaluran obat dari Apotek kepada pasien" dan menurut Peraturan Kepala BPOM Tahun 2012 yaitu "Fasilitas distribusi harus memastikan penyaluran narkotika dan psikotropika ke fasilitas distribusi lain yang memiliki ijin khusus penyalur narkotika dan psikotropika, instalasi sediaan farmasi, apotek dan rumah sakit yang memiliki kewenangan menyalurkan atau menyerahkan narkotika dan psikotropika sesuai dengan peraturan perundang-undangan", dimana pada penyaluran ini terkait obat keras disertai dengan resep dokter juga pelayanan untuk narkotika dan psikotropika harus ditangani dengan khusus dan wajib memakai resep dokter.

\section{Aspek Penanganan Produk Kembalian dan Kadaluarsa}

Aspek penanganan produk kembalian dan kadaluarsa didapat dari lima belas Apotek di Wilayah Kecamatan Cikupa Kabupaten Tangerang, data dapat dilihat pada tabel 6 .

Tabel 6. Aspek Penanganan Produk Kembalian dan Kadaluarsa

\begin{tabular}{clcc}
\hline No. & \multicolumn{1}{c}{$\begin{array}{c}\text { Aspek Penanganan } \\
\text { Produk Kembalian dan } \\
\text { Kadaluarsa }\end{array}$} & Ya & Tidak \\
\hline 1. & $\begin{array}{l}\text { Apotek pernah melakukan } \\
\text { pengembalian barang } \\
\text { kepada distributor. }\end{array}$ & $73,3 \%$ & $26,7 \%$ \\
2. & $\begin{array}{l}\text { Apotek selalu } \\
\text { menyertakan faktur } \\
\text { pembelian saat proses } \\
\text { pengembalian barang } \\
\text { kepada distributor. }\end{array}$ & $73,3 \%$ & $26,7 \%$ \\
\hline \multicolumn{1}{c}{ Total } & $\mathbf{7 3 , 3 \%}$ & $\mathbf{2 6 , 7 \%}$ \\
\hline
\end{tabular}

Berdasarkan tabel 6 pada aspek penanganan produk kembalian dan kadaluarsa $73,3 \%$ Apotek sesuai dengan Peraturan Kepala BPOM Tahun 2012 dan 26,7\% tidak sesuai. Berdasarkan penelitian dari Isna Sugih Hartini dan Marchaban yaitu "Aspek ini berkaitan dengan proses pengembalian produk kadaluarsa dan kembalian kepada distributor beserta kelengkapan surat - suratnya" dan menurut Peraturan Kepala BPOM Tahun 2012 yaitu "Jumlah dan identifikasi obat dan atau bahan obat kembalian harus dicatat dalam catatan penerimaan dan pengembalian barang". Berdasarkan hal tersebut jika Apotek melakukan pengembalian harus selalu menyertakan faktur pembelian kepada distributor.

\section{Aspek Pemusnahan}

Aspek pemusnahan didapat dari lima belas Apotek di Wilayah Kecamatan Cikupa Kabupaten Tangerang, data dapat dilihat pada tabel 7.

Tabel 7. Aspek Pemusnahan

\begin{tabular}{|c|c|c|c|}
\hline No & Aspek Pemusnahan & Ya & Tidak \\
\hline 1. & $\begin{array}{l}\text { Pelaksanakan prosedur } \\
\text { pemusnahan } \\
\text { narkotika dan psikotropika } \\
\text { di Apotek disaksikan oleh } \\
\text { Apoteker dan Dinkes. }\end{array}$ & $53,3 \%$ & $46,7 \%$ \\
\hline 2. & $\begin{array}{l}\text { Pelaksanakan prosedur } \\
\text { pemusnahan obat rusak } \\
\text { dan kadaluarsa di Apotek } \\
\text { disaksikan oleh Apoteker } \\
\text { dan Tenaga Kefarmasian } \\
\text { yang memiliki surat izin } \\
\text { praktik atau surat izin } \\
\text { kerja. }\end{array}$ & $80 \%$ & $20 \%$ \\
\hline 3. & $\begin{array}{l}\text { Apotek menyertakan surat- } \\
\text { surat yang lengkap saat } \\
\text { melakukan prosedur } \\
\text { pemusnahan. }\end{array}$ & $66,7 \%$ & $33,3 \%$ \\
\hline 4. & $\begin{array}{l}\text { Proses pemusnahan obat } \\
\text { dilakukan dalam jangka }\end{array}$ & $73,3 \%$ & $26,7 \%$ \\
\hline
\end{tabular}




\begin{tabular}{rrrr}
$\begin{array}{l}\text { waktu } \\
\text { ditetapkan. }\end{array}$ & telah & \\
\hline Total & $\mathbf{6 8 , 3 \%}$ & $\mathbf{3 1 , 7 \%}$ \\
\hline
\end{tabular}

Berdasarkan tabel 7 pada aspek pemusnahan yaitu tentang pemusnahan yang dilakukan oleh Apotek dan siapa saja yang menyaksikan proses pemusnahan serta kelengkapan surat-surat pada proses pemusnahan. Pada aspek ini $68,3 \%$ sesuai dengan Peraturan Kepala BPOM Tahun 2012 dan $31,7 \%$ belum sesuai. Pada aspek ini sebagian Apotek tidak melakukan pemusnahan dikarenakan Apotek membeli dan memesan sesuai dengan kebutuhan atau sedikit, dan menjual obat-obat fast moving atau yang sering pasien butuhkan sehingga obat tidak sampai kadaluarsa. Hal ini sesuai dengan Peraturan Kepala BPOM Tahun 2012 yaitu "Obat kadaluarsa atau rusak harus dimusnahkan sesuai dengan jenis dan bentuk sediaan. Pemusnahan Obat kadaluarsa atau rusak yang mengandung narkotika atau psikotropika dilakukan oleh Apoteker dan disaksikan oleh Dinas Kesehatan Kabupaten atau Kota. Pemusnahan Obat selain narkotika dan psikotropika dilakukan oleh Apoteker dan disaksikan oleh Tenaga Kefarmasian lain yang memiliki surat izin praktik atau surat izin kerja. Pemusnahan dibuktikan dengan berita acara pemusnahan".

\section{KESIMPULAN}

Pelaksanaan distribusi obat di lima belas Apotek yang berada di Wilayah Kecamatan Cikupa Kabupaten Tangerang yang sesuai dengan Peraturan Kepala BPOM Nomor HK.03.1.34.11.12.7542 Tahun 2012 dalam hal Aspek Profil Sarana sebesar 77,3\%, Aspek Bangunan dan Peralatan sebesar 83,3\%, aspek pengadaan sebesar $72.2 \%$, aspek penerimaan dan penyimpanan sebesar $91,1 \%$, aspek penyaluran sebesar $44,4 \%$, aspek penanganan produk kembalian dan kadaluarsa sebesar $73,3 \%$, dan aspek pemusnahan sebesar $68,3 \%$.

\section{DAFTAR PUSTAKA}

Agustyani, V., Utami, W., Sumaryono, W dan Rahem, A. 2017. Evaluasi Penerapan CDOB sebagai Sistem Penjaminan Mutu pada Sejumlah PBF di Surabaya. Jurnal Universitas Airlangga. Surabaya.

Badan Pengawas Obat dan Makanan. 2012.
Peraturan Kepala Badan Pengawas Obat dan Makanan Republik Indonesia Nomor HK.03.1.34.11.12.7542 Tentang Pedoman Teknis Cara Distribusi Obat yang Baik, Badan Pengawas Obat dan Makanan RI. Jakarta.

Badan Pengawas Obat dan Makanan. 2015. Petunjuk Pelaksanaan Cara Distribusi Obat Yang Baik. Badan Pengawas Obat dan Makanan RI. Jakarta.

Badan Pengawas Obat dan Makanan. 2018. Peraturan Badan Pengawas Obat Dan Makanan Nomor 4 Tahun 2018 Tentang Pengawasan Pengelolaan Obat, Bahan Obat, Narkotika, Psikotropika, Dan Prekursor Farmasi Di Fasilitas Pelayanan Kefarmasian. Badan Pengawas Obat dan Makanan RI. Jakarta.

Hartini, I.S. dan Marchaban. 2016. Evaluasi Pelaksanaan Cara Distribusi Obat Yang Baik (CDOB) Pada Apotek Di Kecamatan Mlati Kabupaten Sleman Yogyakarta. Jurnal Universitas Gajah Mada. Yogyakarta.

Komite Farmasi Nasional. 2014. Pedoman ReSertifikasi Apoteker Dan Penentuan Satuan Kredit Partisipasi (Skp). Jakarta.

Peraturan Menteri Kesehatan RI. 2016. Peraturan Menteri Kesehatan Republik Indonesia Nomor 73 Tentang Standar Pelayanan Kefarmasian di Apotek. Kementrian Kesehatan RI. Jakarta.

Peraturan Menteri Kesehatan RI. 2017. Peraturan Menteri Kesehatan Republik Indonesia Nomor 9 Tentang Apotek. Kementrian Kesehatan RI. Jakarta.

Peraturan Pemerintah Republik Indonesia. 2009. Peraturan Pemerintah Republik Indonesia Nomor 51 Tahun 2009 Tentang Pekerjaan Kefarmasian. Presiden Republik Indonesia. Jakarta.

Ratulangi, R.S, dan Soegoto, A.S. 2016. Pengaruh Pengalaman Kerja, Kompetensi, Motivasi Terhadap Kinerja Karyawan (Studi Pada Pt. Hasjrat Abadi Tendean Manado). Jurnal Universitas Sam Ratulangi Manado. Manado.

Sinen, Y., Lolo, W. A. dan Supriati, H. S. 2017. Evaluasi penyimpanan dan pendistribusian obat di pt. unggul jaya cipta usaha manado. Jurnal Universitas Sam Ratulangi Manado. Manado. 